\title{
KONTRIBUSI USAHA TERNAK ITIK PETELUR TERHADAP PENDAPATAN RUMAHTANGGA PETANI PETERNAK DI KECAMATAN LANGOWAN TIMUR
}

\author{
Lidya Y. Turangan, M. A. V. Manese*, S. P. Pangemanan \\ Fakultas Peternakan Universitas Sam Ratulangi Manado, 95115
}

\begin{abstract}
ABSTRAK
Tujuan dari penelitian ini untuk mengetahui kontribusi usaha ternak itik petelur di Kecamatan Langowan Timur terhadap pendapatan rumahtangga petani peternak. Penelitian ini dilaksanakan pada tanggal 01 Oktober 2018 sampai tanggal 28 Oktober 2018. Pengumpulan data penelitian ini menggunakan metode survey dan wawancara dengan menggunakan kuesioner. Penentuan sampel dilakukan dengan cara purposive sampling dengan pertimbangan memiliki ternak minimal 100 ekor dan melakukan usaha itik petelur secara tradisional. Jumlah sampel yaitu mengambil keseluruhan petani peternak yang masuk dalam kriteria (Total Samping) yang kemudian dibagi menjadi 3 skala kepemilikan ternak. Skala 1 (100-233 ekor) memperoleh pendapatan Rp 29.175.786/tahun, skala 2 (234-367 ekor) memperoleh pendapatan Rp 52.685.974/tahun dan skala 3 (368-500 ekor) memperoleh pendapatan $\mathrm{Rp}$ 72.364.195/tahun. Usaha itik di Kecamatan Langowan Timur umumnya masih dipelihara secara tradisional dengan sistem pemeliharaan semiintensif dan sebagian besar petani peternak menggunakan sistem gembala. Pendapatan rumahtangga petani peternak itik petelur tradisional diperoleh dari usaha itik yang memberikan kontribusi paling tinggi
\end{abstract}

Korespondensi (corresponding author)

Email: merry_manese@unsrat.ac.id sebesar 89\% dengan nilai $\mathrm{Rp}$ 154.225.952/tahun, usahatani milik orang lain (off farm) yang memberikan kontribusi $1 \%$ dengan nilai $\mathrm{Rp}$ 2.304.678/tahun dan diluar usahatani (non farm) yang memberikan kontribusi $10 \%$ dengan nilai Rp 17.441.667/tahun. Hal ini dapat disimpulkan bahwa usaha itik merupakan usaha utama yang memberikan pendapatan lebih besar dari usaha-usaha lain. Usaha ternak itik merupakan sumber pendapatan rumahtangga bagi petani peternak dan memberikan kontribusi yang cukup besar yaitu $89 \%$ dibandingkan dengan usaha-usaha lainnya.Semakin besar skala kepemilikan ternak itik, semakin besar pula pendapatan yang akan diterima. Sistem pemeliharaan usaha ternak itik petelur di Kecamatan Langowan Timur masih tradisional dan perlu dikembangkan karena melihat potensi lahan pertanian yang cukup luas dapat menyediakan pakan alam sehingga menguntungkan peternak.

Kata Kunci: Usaha Itik, pendapatan, rumahtangga

\begin{tabular}{lr}
\multicolumn{3}{c}{ ABSTRACT } \\
DUCKS \\
CONTRIBUTION & FARM \\
HOUSEHOLDS INCOME IN EAST \\
LANGOWAN DISTRICT. The
\end{tabular}
purpose of this research was to evaluate duck layer farm contribution on household domestic income in East Langowan district. This study was conducted on October 1st to 28th, 2018. The data were obtained by applying 
survey methods and interviews completed the questionnaires. Samples were taken by purposive sampling methods involving 100 adult ducks maintained traditionally. The samples number is obtained from the whole household farmers, divided into 3 scales of livestock ownership. Scale 1 was farmers with 100 to 233 duck earning revenue of IDR 29.175.786 per year. Scale 2 was farmers with 234 to 367 ducks earning revenue of IDR 52.685.974 per year. Scale 3 was farmers with 368 to 500 ducks earning revenues of IDR 72.364.195 per year. Generally, the duck farm in East Langowan district was still traditionally maintained under a semi-intensive maintenance system. The household farmers of the laying ducks contributed the highest income of $89 \%$ with a value of IDR 154.225.952 per year. Animal farm of other owners (off farm) contributed $1 \%$ with the value of IDR 2.304.678 per year. Sources of non farming contributed $10 \%$ with the value of IDR 17.441.667 per year. It can be concluded that duck farm was categorized into a major farming industry providing greater revenues than other businesses. Duck farm was a source of household farmer income contributing $85 \%$ compared with other businesses. The greater the scale of the livestock ownership, the greater the income will be received. The laying duck maintenance system in East Langowan district was still categorized in a traditional system, important to be developed because of potential of agricultural land can provide natural feed so as to profitable breeders.

Keywords: ducks, income, households.

\section{PENDAHULUAN}

Pengembangan peternakan yang

terintegrasi merupakan salah satu pilar pembangunan ekonomi untuk memenuhi kecukupan pangan terutama protein hewani (Mayulu et al., 2010). Dalam rangka pemenuhan kebutuhan protein hewani maka pemerintah dan peternak berusaha mendayagunakan berbagai sumber komoditas ternak diantaranya yaitu ternak itik. Menurut Sandi et al. (2016), secara nasional populasi ternak itik terus meningkat dari tahun ke tahun. Pada tahun 2018, diketahui itik yang tersebar di seluruh provinsi di Indonesia telah mencapai lebih dari 47 juta ekor.

Minahasa merupakan salah satu Kabupaten di Sulawesi Utara, terletak di ujung Utara pulau Sulawesi. Ibukota Kabupaten Minahasa adalah Tondano, berjarak sekitar $35 \mathrm{~km}$ dari Manado, ibukota Provinsi Sulawesi Utara. Peternakan itik di Kabupaten Minahasa berkembang cukup banyak (BPS Sulut, 2018). Kabupaten Minahasa memiliki potensi sumber daya alam yang sesuai dengan perkembangan ternak itik. Menurut penelitian Pangemanan (2014), peternakan itik sudah lama dikembangkan khususnya di daerah pinggiran danau Tondano yang memiliki luas 4.620 ha dan daerah persawahan yang cukup luas yaitu 13.002 ha. 
Salah satu usaha ternak yang dijalankan di Kecamatan Langowan Timur, Kabupaten Minahasa yaitu usaha ternak itik petelur. Menurut Badan Pusat Statistik Kabupaten Minahasa (2018), populasi terbanyak dari ternak itik adalah di Kecamatan Langowan Timur dan menjadi sentra pengembangan ternak itik.

Usaha itik petelur di Minahasa umumnya masih dipelihara secara tradisional yang kegiatannya berdasarkan pengalaman beternak orang tua mereka secara turun temurun, skala pemeliharaan kecil, menggunakan bibit dan pakan lokal, kandang sederhana, masih menggunakan peralatan yang sederhana, tidak menggunakan obatobatan dan menggunakan itik lokal, pemeliharaan dengan melepas ternak (Polakitan et al., 2015). Menurut penelitian Pangemanan (2014), peternak itik tradisional di Kabupaten Minahasa biasanya menggunakan system penggembalaan dan semi-intensif, yang paling sering digunakan yaitu sistem penggembalaan yaitu dengan melepas ternak di daerah persawahan yang habis panen. Sistem ini lebih menguntungkan peternak karena menggunakan peralatan yang sederhana dan memanfaatkan pakan alam sehingga mengurangi biaya pakan.

Hasil usaha ternak itik berupa telur dan daging sudah dapat memenuhi kebutuhan rumahtangga dan bahkan dijadikan sebagai mata pencaharian bagi rumahtangga petani peternak itik di Minahasa. Menurut Sinaga et al. (2014) ternak itik sudah popular dan mampu menciptakan lapangan kerja bagi masyarakat di Indonesia. Keberhasilan usaha peternakan ditentukan oleh 3 (tiga) faktor utama yaitu pembibitan (breeding), pakan (feeding), dan manajemen. Pembibitan yaitu pemilihan bibit unggul yang dibutuhkan peternak skala kecil, skala menengah dan skala besar secara berkelanjutan. Dalam hal pakan yaitu pemilihan pakan yang baik, waktu pemberian pakan, jumlah pakan yang diberikan, serta teknik pemberian pakan. Sedangkan manajemen yaitu tentang bagaimana mengelola peternakan tersebut.

Rumahtangga petani peternak itik petelur tradisional di Kecamatan Langowan Timur, Kabupaten Minahasa memperoleh pendapatan dari usahausaha seperti usahatani (On farm), bekerja di sawah/kebun milik orang (Off farm), ada juga yang bekerja diluar usahatani contohnya pegawai, ojek, dan 
sebagainya (Non farm). Usaha ternak itik petelur merupakan salah satu sumber pendapatan rumahtangga petani peternak yang dapat merupakan usaha utama maupun usaha sampingan. Potensi daerah dan sumber daya alam di daerah ini sangat bagus untuk produksi ternak itik sehingga dapat menjadi komoditas bagi sumber pendapatan petani peternak.

\section{METODE PENELITIAN}

Penelitian ini dilaksanakan di Kecamatan Langowan Timur pada tanggal 01 Oktober sampai tanggal 28 Oktober 2018. Pengumpulan data dilakukan dengan metode survey dan wawancara secara mendalam dengan menggunakan kuesioner. Penentuan sampel dilakukan secara purposive sampling dengan pertimbangan memiliki ternak minimal 100 ekor dan melakukan usaha ternak itik petelur secara tradisional. Menurut Ferdian et al. (2012), purposive sampling adalah teknik pengambilan sampel dengan pertimbangan orang tersebut yang dianggap paling tahu tentang apa yang kita harapkan, atau mungkin dia sebagai penguasa sehingga akan memudahkan peneliti menjelajahi objek atau situasi sosial yang diteliti. Penentuan jumlah sampel menggunakan total sampling yaitu dengan mengambil keseluruhan petani peternak di Kecamatan Langowan Timur yang masuk dalam kriteria dan kemudian dibagi menjadi 3 skala kepemilikan. Skala 1 (100-233 ekor), skala 2 (234-367 ekor) dan skala 3 (368-500 ekor). Kondisi dan profil usaha peternakan itik petelur tradisional di Kecamatan Langowan Timur digambarkan dengan menggunakan model analisis deskriptif yaitu menguraikan secara kualitatif keadaan riil profil rumahtangga petani peternak itik petelur tradisional dan usaha peternakan itik petelur tradisional di Kecamatan Langowan Timur. Data yang dikumpulkan selanjutnya akan ditabulasi dan dianalisis dengan menggunakan pendekatan analisis deskriptif sebagai pemecahan masalah dengan menggambarkan keadaan objek penelitian berdasarkan fakta-fakta yang ada.

Untuk mengetahui biaya produksi, penerimaan dan pendapatan usaha ternak itik petelur dihitung dengan menggunakan rumus:

dimana,

$$
\pi=\mathbf{T R}-\mathbf{T C}
$$

$\pi \quad$ :Pendapatan usahatani/ternak (Rp/Thn)

TR :Total penerimaan usahatani/ternak ( $\mathrm{Rp} / \mathrm{Thn})$

TC :Total biaya yang dikeluarkan dalam usahatani/ternak (Rp/Thn) 
dimana,

$$
\mathbf{T R}=\mathbf{P} \times \mathbf{Q}
$$

$\mathrm{P} \quad$ :Harga per satuan unit (Rp)

Q :Produksi usahatani/ternak

$$
\mathbf{T C}=\mathbf{F C}+\mathrm{VC}
$$

dimana,

TC : Total biaya $(\mathrm{Rp} / \mathrm{Thn})$

FC : Biaya tetap (Rp/Thn)

VC : Biaya variabel (Rp/Thn)

Untuk mengetahui kelayakan usaha penjualan itik petelur tradisional di Kecamatan Langowan Timur dapat menggunakan rumus R/C Ratio (Revenue per Cost Ratio), yaitu perbandingan antara total penerimaan dan total biaya (Suharda et al., 2015). Apabila nilai (R/C Ratio) > 1, maka usahanya layak. Apabila nilai (R/C Ratio) $=1$, maka usahanya impas. Apabila nilai $(\mathrm{R} / \mathrm{C}$ Ratio $)<1$, maka usahanya tidak layak.

dimana,

$$
\mathrm{R} / \mathrm{C} \text { Ratio }=\frac{\text { Revenue }}{\text { Cost }}
$$

$\mathrm{R} \quad$ : Penerimaan (Rp/tahun)

C : Biaya (Rp/tahun)

Total pendapatan rumahtangga petani peternak itik petelur tradisional dihitung dengan menggunakan rumus:

Pdpt RT Petani Peternak = Pdpt Usaha On Farm + Pdpt Usaha Off Farm + Pdpt Usaha Non Farm + Pdpt Remitan
Kontribusi pendapatan usaha itik petelur dihitung dengan menggunakan rumus persentase:

Kontribusi(\%)

$=\frac{\text { Pendapatan Usaha Itik Petelur }}{\text { Total Pendapatan Rumah Tangga }} \times 100 \%$

HASIL DAN PEMBAHASAN

\section{Keadaan Umum Kecamatan Langowan Timur}

Kecamatan Langowan Timur terdiri dari 8 wilayah desa, luas daratan masing-masing desa, yaitu Amongena Satu $\left(2,40 \mathrm{~km}^{2}\right)$, Amongena Dua $(0,71$ $\left.\mathrm{km}^{2}\right)$, Amongena Tiga $\left(2,14 \mathrm{~km}^{2}\right)$, Wolaang (2,14 $\left.\mathrm{km}^{2}\right)$, Sumarayar $(2,01$ $\left.\mathrm{km}^{2}\right)$, Karondoran $\left(0,95 \mathrm{~km}^{2}\right)$, Teep $\left(2,01 \mathrm{~km}^{2}\right)$ dan Waleure $\left(0,93 \mathrm{~km}^{2}\right)$. Jarak hubungan transportasi dari pusat kecamatan ke pusat kabupaten $\pm 20 \mathrm{~km}$ dan jarak ke ibukota provinsi $\pm 65 \mathrm{~km}$. Jumlah penduduk 12.645 orang (BPS Kabupaten Minahasa, 2018). Sebagian besar penduduk di daerah ini bermata pencaharian sebagai petani dan pedagang. Kecamatan Langowan Timur merupakan pusat perdagangan terbesar di Kecamatan Langowan sehingga menunjang pemasaran telur dan daging itik.

\section{Karakteristik Responden}


Tabel 1. Karakteristik Responden

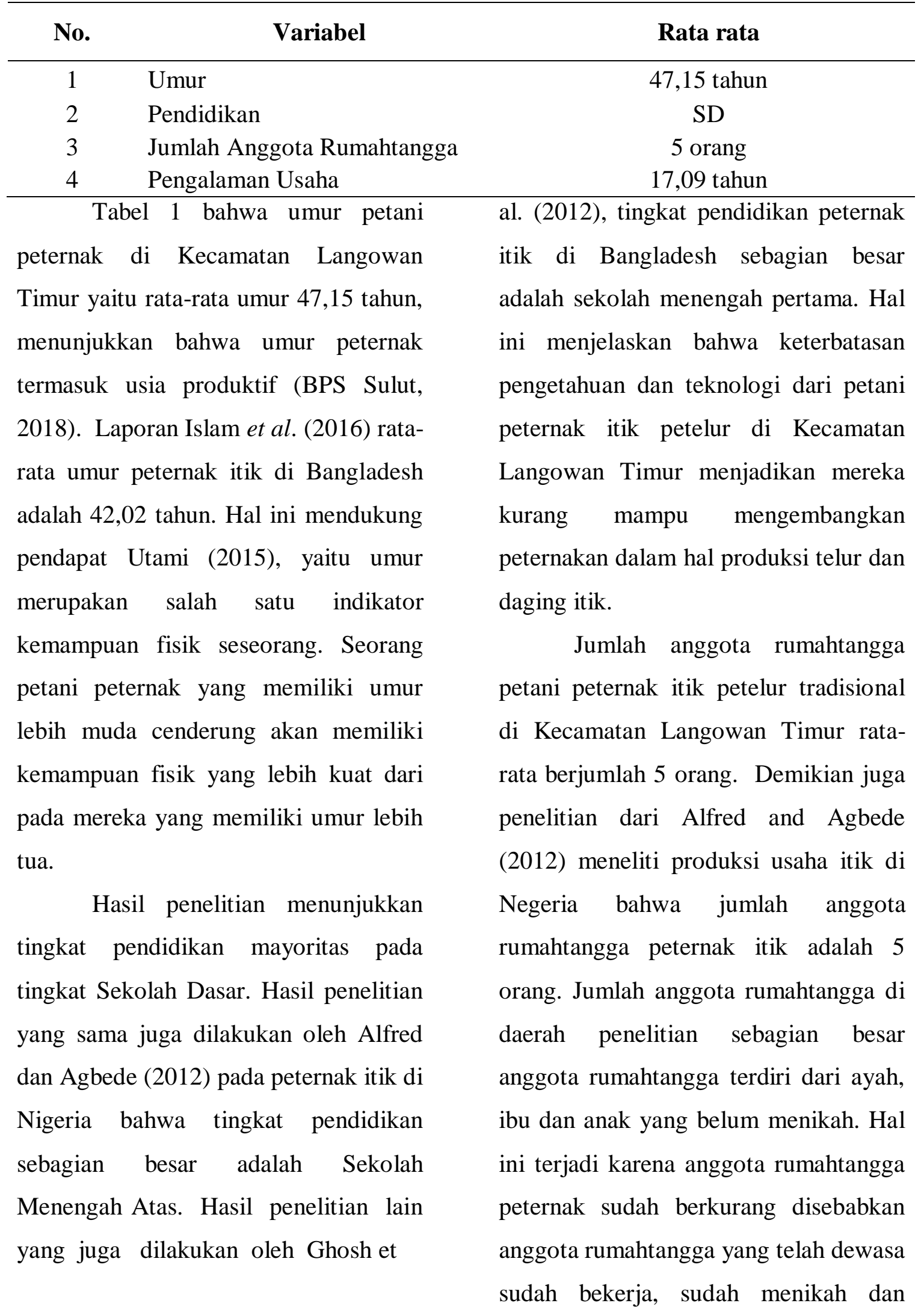


memilih untuk hidup mandiri atau berpisah dengan orang tua.

Berdasarkan hasil penelitian, petani peternak yang mempunyai lama usaha petani peternak itik petelur di Kecamatan Langowan Timur berkisar antara 10-40 tahun dengan rata-rata lama beternak 17,09 tahun. Hasil penelitian ini hampir sama dengan penelitian dari Islam et al. (2016) bahwa rata-rata lama usaha beternak di Bangladesh adalah 13,88 tahun. Hal ini menggambarkan bahwa petani peternak itik petelur di Kecamatan Langowan Timur sudah mempunyai cukup pengalaman beternak karena mereka mengelola usahanya dengan cara tradisional yaitu turun temurun mengikuti kebiasaan orang tuanya, sehingga mereka memiliki pengetahuan beternak dan mendirikan usaha ini sebagai salah satu sumber pendapatan rumahtangga baik usaha utama maupun usaha sampingan.

\section{Sistem Pemeliharaan}

Sistem pemeliharaan yang dilakukan petani peternak itik petelur di Kecamatan Langowan Timur adalah sistem gembala dan sistem pemeliharaan semi intensif. Sistem gembala sudah menjadi tradisi yang telah turun-temurun dari orang tua petani peternak yaitu dengan peternak melepas ternak itik di daerah yang menyediakan pakan alam berupa keong, butiran padi sisa, serangga dan lainnya yaitu persawahan habis panen dan berpindah-pindah lokasi gembala memenuhi kebutuhan pakan ternak bahkan sampai daerah jauh dari tempat tinggal petani peternak. Petani peternak merasa sistem ini sangat menguntungkan karena peralatan yang digunakan sederhana dan memanfaatkan sumber pakan alam sehingga dapat mengurangi biaya pakan. Pemeliharaan sistem semi intensif (kandang) hanya beberapa peternak yang menggunakannya yaitu dengan cara mengkandangkan ternak itiknya secara rutin untuk menjaga pertumbuhan dan produksi telur dan ada juga saat dimana ternak akan dilepas untuk makan di alam. Waktu penggembalaan ternak itik petelur di Kecamatan Langowan Timur dimulai dari jam 6 pagi sampai jam 5 sore, bahkan ada beberapa petani peternak yang ikut tinggal menjaga ternak itik petelur di daerah gembala tersebut. Pada daerah gembala tersebut dibuat kandang sederhana yang terbuat dari pagar bambu yang dikelilingi oleh jaring, terpal sebagai atap dan pada lantai tanah 
dialasi dengan jerami padi, bertujuan untuk melindungi ternak itik petelur dari hujan, sebagai pelindung pada malam hari, sebagai pelindung dari gangguan hewan lain ataupun pencuri, juga supaya lebih mudah dalam mengumpulkan telur itik. Sistem pemeliharaan semi insentif biasanya dilakukan oleh peternak yang memiliki usaha lain, yaitu sebagai petani atau ojek. Kandang sistem semi intensif di Kecamatan Langowan Timur yaitu kandang dibuat di daerah dekat rawa atau danau. Kandang terbuat dari bambu dan jaring yang dijadikan pagar, terpal atau seng sebagai atap dan jerami padi sebagai alas. Pemeliharaan sistem semi intensif ini, tidak menggunakan obat ternak karena ternak itik petelur dianggap tahan penyakit dan tahan cuaca yang berubah-ubah. Dari hasil penelitian, pada umumnya ternak yang mati karena digigit oleh hewan lain. Bibit yang digunakan oleh peternak adalah bibit lokal dan bibit-bibit ini diambil dari hasil produksi ternak sebelumnya, bahkan ada peternak yang sudah tidak tahu asal bibitnya karena turun temurun dari hasil produksi orang tua mereka. Untuk penetasan, ada beberapa petani peternak yang menggunakan mesin tetas, tapi sebagian besar menggunakan indukan entok/ayam.

Pendapatan Usaha Ternak Itik Berdasarkan Skala Usaha

Hasil penelitian di Kecamatan Langowan Timur ada 34 orang petani peternak yang memiliki ternak itik petelur tradisional minimal 100 ekor dan kemudian dibagi menjadi 3 skala sesuai dengan skala kepemilikan ternak.

Tabel 2. Pendapatan Usaha Itik Berdasarkan Skala

\begin{tabular}{lcccc}
\hline & Skala 1 & Skala 2 & Skala 3 & $\begin{array}{c}\text { Total } \\
\text { (Rp/tahun) }\end{array}$ \\
\hline Penerimaan & 84.136 .144 & 135.889 .026 & 195.698 .567 & $\mathbf{4 1 5 . 7 2 3 . 7 3 7}$ \\
Biaya Produksi & 54.960 .358 & 83.203 .052 & 123.334 .375 & $\mathbf{2 6 1 . 4 9 7 . 7 8 5}$ \\
Pendapatan & 29.175 .786 & 52.685 .974 & 72.364 .192 & $\mathbf{1 5 4 . 2 2 5 . 9 5 2}$ \\
\hline
\end{tabular}


Hasil analisis pada Tabel 1 menunjukkan bahwa pada Skala 1 (100233 ekor), total pendapatan sebesar Rp 2.431.315/bulan atau Rp 29.175.786/tahun. Pada Skala 2 (234367 ekor), total pendapatan sebesar $\mathrm{Rp}$ 4.390.498/bulan atau $\mathrm{Rp}$ 52.685.974/tahun. Pada Skala 3 (368500 ekor), total pendapatan sebesar $\mathrm{Rp}$ 6.030.349/bulan atau Rp 72.364.195/tahun. Dapat dilihat bahwa pendapatan terbesar ada pada pemeliharaan ternak itik petelur tradisional Skala 3 dan disarankan untuk menjalankan usaha pada Skala 2 ke atas karena pendapatan lebih tinggi dari UMP tahun 2018 yaitu Rp 2.824.286/bulan. Semakin besar skala kepemilikan ternak, maka semakin besar pula pendapatan yang akan diperoleh. Penelitian ini juga dilakukan oleh Subagia et al. (2017) yaitu pendapatan usaha itik petelur di Kabupaten Jember skala kurang dari 100 ekor sebesar Rp 656.408/bulan atau Rp 7.876.896/tahun, skala 100 sampai 500 ekor sebesar Rp 2.346.371/bulan atau Rp 28.156.452/tahun, dan skala lebih dari 500 ekor sebesar Rp 28.597.866/bulan atau $\mathrm{Rp}$ 343.174.392/tahun. Hal ini menunjukkan pendapatan usaha ternak itik petelur tradisional di daerah penelitian sudah cukup bagus dibandingkan dengan pendapatan usaha itik di Kabupaten Jember, diduga pendapatan yang diperoleh tinggi karena pemeliharaan sistem gembala dapat mengurangi biaya pakan.

\section{Biaya Produksi, Penerimaan dan Pendapatan}

Pada Tabel 3 biaya produksi diklasifikasikan menjadi 2, yaitu biaya tetap adalah biaya yang jumlahnya tetap dan tidak tergantung pada besar kecilnya jumlah produksi, seperti penyusutan kandang dan peralatan, serta biaya variabel adalah biaya yang berubah bila ada perubahan jumlah produksi yang dihasilkan, seperti biaya bibit, biaya pakan, biaya tenaga kerja, dan transportasi. Penerimaan usaha ini diperoleh dari nilai jual ternak itik baik itik dara maupun itik afkir, penjualan daging dan penjualan telur. Pendapatan dalam usaha ini adalah total penerimaan usaha itik dikurangi biaya-biaya produksi. 
Tabel 3. Total Biaya Produksi, Total Penerimaan dan Keuntungan Dalam Skala

\begin{tabular}{rlcccc}
\hline \multicolumn{1}{c}{ Jenis Biaya } & Skala 1 & Skala 2 & Skala 3 & $\begin{array}{c}\text { Jumlah } \\
\text { (Rp/tahun) }\end{array}$ \\
\hline I & $\begin{array}{l}\text { Biaya Tetap } \\
\text { Biaya penyusutan } \\
\text { kandang/alat }\end{array}$ & 38.421 & 52.970 & 77.300 & 168.691 \\
II & $\begin{array}{l}\text { Biaya Variabel } \\
\text { Biaya pakan }\end{array}$ & 42.798 .568 & 64.787 .457 & 98.861 .400 & 206.447 .425 \\
& $\begin{array}{l}\text { Biaya bibit } \\
\text { Biaya tenaga kerja }\end{array}$ & 7.690 .789 & 6.188 .100 & 9.380 .000 & 19.258 .889 \\
& Biaya transportasi & 664.211 & 2.696 .400 & 2.968 .800 & 6.329 .411 \\
\hline III & $\begin{array}{l}\text { Total Biaya } \\
\text { Produksi }\end{array}$ & $\mathbf{5 4 . 9 6 4 . 3 5 7}$ & $\mathbf{8 3 . 2 0 3 . 0 5 2}$ & $\mathbf{1 2 3 . 3 3 4 . 3 7 5}$ & $\mathbf{2 6 1 . 5 0 1 . 7 8 4}$ \\
\hline IV & Total Penerimaan & $\mathbf{8 4 . 1 3 6 . 1 4 4}$ & $\mathbf{1 3 5 . 8 8 9 . 0 2 6}$ & $\mathbf{1 9 5 . 6 9 8 . 5 6 7}$ & $\mathbf{4 1 5 . 7 2 3 . 7 3 7}$ \\
V & Pendapatan & $\mathbf{2 9 . 1 7 1 . 7 8 7}$ & $\mathbf{5 2 . 6 8 5 . 9 7 4}$ & $\mathbf{7 2 . 3 6 4 . 1 9 2}$ & $\mathbf{1 5 4 . 2 2 1 . 9 5 3}$ \\
\hline
\end{tabular}

Total biaya produksi sebesar Rp 21.791.815/bulan atau Rp 261.501.784/tahun. Total penerimaan sebesar Rp 34.643.645/bulan atau Rp 415.723.737/tahun. Total keuntungan sebesar Rp 12.851.829/bulan atau Rp 154.221.953/tahun. Total penerimaan usaha itik petelur di daerah penelitian sudah cukup bagus dibandingkan dengan hasil penelitian Sinaga et al. (2014) di Kecamatan Bandar Khalifah Kabupaten Serdang Begadai yang memperoleh total penerimaan sebesar Rp 44.577.000/tahun. Keuntungan yang diperoleh di daerah penelitian sebesar Rp 1.443.020.637/tahun. Penelitian lain juga dilakukan oleh Mulyono et al. (2017) di Kecamatan Banyubiru
Kabupaten Semarang Jawa Tengah dengan rata-rata keuntungan usaha itik adalah sebesar 1.917.808/bulan atau Rp 23.013.696/tahun.

\section{Penerimaan Lain}

Penerimaan lain diperoleh dari pendapatan off farm adalah pendapatan yang diperoleh dari kegiatan usaha tani yang dilakukan rumahtangga petani peternak diluar usaha tani miliknya, yaitu buruh tani sebesar $\mathrm{Rp}$ 192.056/bulan atau Rp 2.304.678/tahun. Pendapatan non farm adalah pendapatan yang diperoleh dari kegiatan usaha yang dilakukan rumahtangga petani peternak yang bukan merupakan usaha pertanian, yaitu ojek, warung dan remitan dengan total pendapatan non farm sebesar Rp 
1.453.472/bulan

atau

$\mathrm{Rp}$

17.441.667/tahun.

\section{Kelayakan Usaha}

Untuk mengetahui kelayakan usaha penjualan itik petelur tradisional di Kecamatan Langowan Timur dapat menggunakan rumus R/C Ratio (Revenue per Cost Ratio), yaitu perbandingan antara total penerimaan dan total biaya (Suharda et al., 2015). Apabila nilai (R/C Ratio) > 1, maka usahanya layak. Apabila nilai (R/C Ratio) = 1, maka usahanya impas. Apabila nilai $(\mathrm{R} / \mathrm{C}$ Ratio $)<1$, maka usahanya tidak layak. Hal ini menggambarkan semakin tinggi nilai R/C Ratio, maka tingkat keuntungan usaha lebih tinggi.

$$
\mathbf{R} / \mathbf{C} \text { Ratio }=\frac{3.935 .969 .832}{2.492 .949 .195}=\mathbf{1 , 5 8}
$$

Berdasarkan hasil perhitungan kelayakan di atas menunjukkan nilai $\mathrm{R} / \mathrm{C}$ Ratio $=1,58$ artinya setiap penambahan Rp 1 akan memberikan keuntungan sebesar 1,58, dengan demikian maka usaha ternak itik petelur tradisional di Kecamatan Langowan Timur dapat dikatakan layak secara finansial.

\section{Kontribusi Usaha Ternak Itik}

Hasil analisis menunjukkan bahwa pendapatan usaha itik memberikan kontribusi sebesar yaitu 89\% dengan nilai Rp 12.852.163/bulan atau Rp 154.225.952/tahun. Usaha off farm memberi kontribusi sebesar $1 \%$ dengan nilai Rp 192.056/bulan atau Rp 2.304.678/tahun. Usaha non farm memberi kontribusi sebesar $10 \%$ dengan nilai $\mathrm{Rp} 1.453 .472 /$ bulan atau Rp 17.441.667/tahun. Hal ini dapat disimpulkan bahwa usaha itik merupakan usaha utama yang memberikan pendapatan lebih besar dari usaha-usaha lain.

Tabel 3. Kontribusi Pendapatan Dalam Skala

\begin{tabular}{lccccc}
\hline & Skala 1 & Skala 2 & Skala 3 & $\begin{array}{c}\text { Total } \\
(\text { Rp/tahun })\end{array}$ & $\begin{array}{c}\text { Persentase } \\
(\%)\end{array}$ \\
\hline Usaha itik & 29.175 .786 & 52.685 .974 & 72.364 .192 & $\mathbf{1 5 4 . 2 2 5 . 9 5 2}$ & 89 \\
Off farm & 1.000 .419 & 649.967 & 654.292 & $\mathbf{2 . 3 0 4 . 6 7 8}$ & 1 \\
Non farm & 10.608 .333 & 6.833 .333 & - & $\mathbf{1 7 . 4 4 1 . 6 6 7}$ & 10 \\
\hline \multicolumn{1}{c}{ Total } & $\mathbf{4 0 . 7 8 4 . 5 3 8}$ & $\mathbf{6 0 . 1 6 9 . 2 7 4}$ & $\mathbf{7 3 . 0 1 8 , 4 8 4}$ & $\mathbf{1 7 3 . 9 7 2 . 2 9 7}$ & $\mathbf{1 0 0}$ \\
\hline
\end{tabular}


Pendapatan usaha itik lebih tinggi dibandingkan dengan Upah Minimum Provinsi Sulawesi Utara pada tahun 2018 yaitu sebesar Rp 2.820.000/bulan. Hasil penelitian ini sama dengan laporan penelitian Setioko dalam Pangemanan (2014) bahwa pendapatan utama rumahtangga peternak itik gembala di Pulau Jawa adalah dari usaha itik sebesar $72 \%$, pendapatan lainnya dari usaha pertanian sebesar $19 \%$, usaha dagang sebesar $5 \%$ dan lainnya $4 \%$.

\section{KESIMPULAN}

Sistem pemeliharaan usaha ternak itik petelur di Kecamatan Langowan Timur masih tradisional sehingga perlu dikembangkan karena berpotensi dan menguntungkan peternak. Usaha ternak itik merupakan sumber pendapatan rumahtangga bagi petani peternak dan memberikan kontribusi yang sangat besar yaitu 95\% dibandingkan dengan usaha-usaha lainnya.Semakin besar skala kepemilikan ternak itik, semakin besar pula pendapatan yang akan diterima.

\section{DAFTAR PUSTAKA}

Alfred S.D.Y. dan J.O. Agbede. 2012. Influencing factors of duck production in the Southwest of Nigeria. African Journal of Agricultural Research 7(24):3498-3505.
Badan Pusat Statistik Kabupaten Minahasa. 2018. Kecamatan Langowan Timur Dalam Angka. Manado.

Badan Pusat Statistik Sulawesi Utara. 2018. Sulawesi Utara Dalam Angka. Manado.

Ferdian, F., I. Maulina dan Rosidah. 2012. Analisis permintaan ikan lele dumbo (Clarias gariepinus) konsumsi di Kecamatan Losarang Kabupaten Indramayu. Jurnal Perikanan dan Kelautan 3(4):93-98.

Ghosh S., N. Haider, and M.K.I Khan. 2012. Status of household's ducks and their associated factors under scavenging system in a Shoutern Area of Bangladesh. International Journal of Natural Sciences 2(4):108-112

Islam, M.A., M.A.R. Howlider, M.A. Alam, M.A. Heyamet and M. Debnath. 2016. Present status, problem and prospect of duck farming in Rural Areas of Mymensingh District Bangladesh. Asian Journal of Medical and Biological Research 2(2):202-212

Mayulu, H., C. Sunarso, S. Imam dan Sumarsono. 2010. Kebijakan pengembangan peternakan sapi potong di Indonesia. Jurnal Litbang Pertanian 29(1):34-41.

Mulyono, A.D., W. Sumekar dan D. Sunarti. 2017. Analisis profitabilitas pengembangan usaha ternak itik di Kecamatan Banyubiru Kabupaten Semarang Jawa Tengah. Jurnal Ilmu Peternakan Terapan 1(1):8-16

Pangemanan, S. 2014. Model Peningkatan Ekonomi 
Rumahtangga Peternak Itik Tradisional di Kabupaten Minahasa Provinsi Sulawesi Utara. Disertasi. Program Pascasarjana, Universitas Brawijaya. Malang.

Polakitan, D., A. Mirah, F.H Elly dan V.V.J. Panalewen. 2015. Keuntungan usahatani padi sawah dan ternak itik di pesisir danau Tondano Kabupaten Minahasa. Jurnal Zootek 35(2): 361-367.

Sinaga, R., S. Lubis dan H. Butar-Butar. 2014. Analisis usaha itik petelur studi kasus Kecamatan Bandar Khalifah Kabupaten Serdang Bedagai. Journal on Social Economic of Agriculture and Agribusiness 2(4):2-7

Suharda, R., L. Fauzia dan Emalisa. 2015. Analisis kelayakan usaha ternak itik (studi kasus Desa Percut, Kecamatan Pecut Sei Tuan, Kabupaten Deli Serdang). Journal on Social Economic of Agriculture and Agribusiness 4(6):1-12

Sandi, R., K. Yulizar dan D.W. Cherrya. 2016. Peternakan bebek Ricki (bekri) (perencanaan pendirian usaha ternak bebek). International Journal of Communication Systems 1(1):1-14.

Subagia, H., N.P Erlina, E. Kustiawan. 2017. Analisis kelayakan usaha peternakan tradisional itik petelur di Kabupaten Jember. Jurnal Ilmu Peternakan Terapan 1(1):39-44

Utami, LS. 2015. Hubungan karakteristik peternak dengan skala usaha ternak kerbau di Desa Sumbang Kecamatan Curio Kabupaten Enrekang.
Skripsi. Fakultas Peternakan. Universitas Hasanuddin. Makassar. 